\title{
O PROBLEMA DA RAZÃO DOS ANIMAIS A PARTIR DA PERSPECTIVA NEOPLATÔNICA
}

\author{
The problem of reason in animals from the \\ Neoplatonic perspective
}

El problema de la razón de los animales desde

la perspectiva neoplatónica

Ronaldo Amaral'

\section{Resumo}

Os pensadores antigos deixaram uma extensa e variada historiografia acerca do estudo sobre os animais, e a contemporaneidade a recobrou. $\mathrm{Na}$ tardia antiguidade, abundantes pesquisas a partir de Plutarco e, em menor número, desde Porfirio, ambos autores de tratados específicos sobre o tema, devem ser ressaltadas. A existência ou não de razão nos animais ou, de outro lado, a discussão e demonstração afirmativa desta, embora fundada em uma natureza e certa dinâmica psicofísica singular à humana, mas nunca quanto a sua essencialidade mesma, cujo princípio é metafísico e uno, constituem alguns dos argumentos abordados. No entanto, em relação a este segundo aspecto, que toca a própria questão da Alma e, como seu corolário, a dinâmica uno-múltiplo nos seres fenomênicos, pouco se disse. Como acreditamos que o estudo sobre a alma seja essencial a nossa discussão, ela é o nosso foco neste estudo.

Palavras-chave: Animais. Razão. Alma. Neoplatonismo. Inteligível.

1 Doutor em História pela Unesp-Assis e pós-doutorado em Filosofia pela PUC-SP. Professor associado do curso de Filosofia e da pós-graduação em Filosofia da UFMS/Campo Grande, MS, Brasil. https://orcid.org/0000-0003-0135-1913. E-mail: ronaldus.amaral@gmail.com. 


\begin{abstract}
The study of animals by Ancient Thought has already recovered an extensive and varied historiography. In the Late Antiquity, there is abundant research from Plutarch and, to a lesser extent, Porphyry, both authors of specific treatises on the subject. The existence or not of reason in animals or, on the other hand, the discussion and affirmative demonstration of this, although founded on psychophysical nature and dynamics similar to the human's one constitute some arguments here explored. But in relation to this second aspect, which touches the very question of the Soul and, as its corollary, the one-multiple dynamics in the phenomenal beings, little was said. As we believe in this topic as essential, this article aims at discussing it.
\end{abstract}

Keywords: Animals. Reason. Soul. Neoplatonism. Intelligible.

\title{
Resumen
}

El estudio sobre los animales en el pensamiento antiguo había recuperado una extensa y variada historiografia. Para la antigüedad tardía subrayanse abundantes investigaciones teniendo como punto de partida Plutarco y, em menor número, Porfirio, ambos autores de tratados específicos sobre el tema. La existencia o no de racionalidad en los animales o, por otra parte, la discusión y la demostración de esta afirmación, aunque apoyada en una naturaleza y dinámica psicofísica singular a lo humano, pero nunca acerca de su misma esencialidad, cuyo principio es metafísico y uno, constituyen algunos de los argumentos planteados. Pero, en este segundo aspecto, que toca a la cuestión del alma y, como corolario, la dinámica uno-múltiplo en los seres fenoménicos, todavia poco se dice. Y, por considerarla esencial para la nuestra discusión a ella nos dedicaremos aquí.

Palabras clave: Animales. Razón. Alma. Neoplatonismo. Inteligible.

\section{O antropocentrismo grego e a afirmação da razão como apanágio do homem pelo conhecimento de si e pelo domínio do mundo}

Os estudos filosóficos acerca dos animais, especialmente nos últimos anos, têm se dedicado sobretudo a uma ética a favor de sua dignidade, tão aviltada pela exploração econômica e pela perda de consciência cósmica com relação à natureza. No entanto, pouco ou nada se realizou no sentido de tentar justificar esse esforço ético por uma compreensão da natureza 
mesma desses seres; ou seja, em observá-los e compreendê-los a partir de seu autorreferimento a partir de sua situação e contato com o mundo. A filosofia antiga, cujos filósofos tinham mais interação com a natureza do que nós, já nos adiantara sobre essa questão. Por isso, desejamos trazer à luz esse importante contributo dos pensadores antigos, neoplatônicos sobretudo, tão distanciados de nós, seja pela tradição antropocêntrica cristã de um lado, seja pelo pensamento moderno laicizante dos últimos séculos, de outro.

Verificar-se-á, portanto, que os animais não humanos foram contemplados com alguma recorrência pelo pensamento filosófico antigo, inclusive pelos pré-socráticos. Embora, por estes últimos, sempre em busca de definir o seu lugar e sua função dentro do cosmos fenomênico, no qual existiriam pelo e para o seu meio estritamente natural e no interior de sua diversidade, ou seja, como seres aquáticos, aéreos, terrestres, etc. $^{2}$. Esse condicionamento ao meio puramente físico, biológico ou, no máximo, psicossomático, transformou o interesse pelos animais em uma existência univocamente natural e biológica. A partir dos socráticos e, sobretudo, da época helenística, somar-se-á a esse interesse puramente físico e biológico, àquele que remeteria a questões morais ou éticas. Os animais seriam, assim, comparados aos humanos, mas a partir de perspectivas e potencialidades existenciais que seriam suas, com a ideia e o discurso reinante da superioridade humana sobre os animais, e isso tanto com relação a sua natureza espiritual/divina quanto psíquico-racional. Os animais poderiam, inclusive, ser submetidos e colocados a serviço do gênero humano, ou seja, escravizados, mortos e transformados em alimento sem qualquer direito natural. Isso porque, afinal, eram seres irracionais e não possuíam uma alma ou, mais precisamente, aquela característica que os conduzisse ao poder da razão. Essa concepção antropocêntrica, que teve Aristóteles como um de seus maiores justificadores, subjugou 
a animalidade ao humano, tanto por seus aspectos físicos quanto pelos aspectos psíquicos e morais.

De toda forma, a literatura filosófica pré-socrática está repleta de comentários e considerações da superioridade dos humanos sobre os animais - o que em nada nos admira diante de um âmbito prevalentemente materialístico ${ }^{3}$ - em função sobretudo de suas características biofísicas. Diógenes de Apolônia, segundo testemunho de Teofrasto que sucedeu a Aristóteles à frente da escola peripatética, defendeu a superioridade humana em comparação aos demais animais, inclusive com desdobramentos para uma superioridade de ordem psíquica graças ao fato de serem eretos e poderem ver mais longe. Tais características deveriam, ademais, acurarem outros tantos sentidos. Logo, os argumentos se voltaram ainda a favor das mãos humanas, pelas quais os homens poderiam aprender, adquirir experiência, capacidade para as artes e, também, em favor da memória, sobretudo porque o acúmulo de experiência era determinante para a formação do próprio pensamento, segundo Anaxágoras ${ }^{4}$.

No que tange propriamente aos aspectos da posse de uma alma ou daquela sua parcela que possibilitaria ao ser sensível ligar-se ou religar-se ao Inteligível, os filósofos antigos demostraram uma tendência ordinária ao considerar, também aqui, os humanos superiores aos animais. Isso se dá na medida em que usufruiriam, para além daquela parte da alma ligada ao sensível, aquela ligada à abstração pura, à inteligência, à parte ou qualidade discursiva, também apanágio dos humanos e por meio da qual os sentidos poderiam ser abstraídos, arrazoados e, o quanto possível, comunicados à inteligência5. Dada superioridade dos homens colocava-os em um lugar

\footnotetext{
3 LANATA, Giuliana. Antropocentrismo e cosmocentrismo nel pensiero antico. In: CASTGNONE, Silvana; LANATA, Giuliana. Filosofi e animali nel mondo antico. Genova: Edizioni Ets, 1994. p. 19.

4 Idem, p. 23.

5 Tomemos o exemplo de Plotino para essa questão, uma vez que o neoplatonismo será o pensamento capitular para esse artigo. Verifica-se, assim, que para Plotino a alma humana possui uma parte sensitiva-vegetativa presa aos simulacros do sensível, às suas vontades e necessidades, não obstante, sendo tal qualidade ou parte da alma a mais elementar nos animais. Nos humanos, por sua vez, haveria uma parte intelectiva que se comunicava imediatamente à
} 
central no próprio Universo, assim como os autorizava a dominar, para sua própria causa e satisfação, as demais criaturas, animadas ao não. Aristóteles parece ser o exemplo mais bem-acabado dessa posição, embora precedido e sucedido de tanto outros congêneres nesse sentido. Como veremos, os platônicos serão o ponto de inflexão diante desta tradição.

De modo que há de pensar, evidentemente, que, de maneira semelhante, as plantas existem para os animais, e os animais para o homem: os domésticos para seu serviço e alimentação; os selvagens, senão todos, ao menos a maior parte, com vistas aos alimentos e outras ajudas, para proporcionar vestimentas e diversos instrumentos. Por conseguinte, se a natureza não faz nada imperfeito e nem em vão, necessariamente produziu todos esses seres à causa do homem ${ }^{6}$.

Aristóteles, mais tarde, em sua Parte dos animais, reafirmará a superioridade humana em relação aos demais animais, inclusive ao retomar argumentos que defendem ser o homem superior, a partir daquela perspectiva prevalentemente fenomênica como já haviam feito os pré-socráticos. Novamente o argumento será a favor da posição ereta dos homens, pela qual, não obstante, seria ainda promovido a uma natureza e a uma condição divina.

É o caso da espécie humana. Trata-se, entre os animais que conhecemos, do único, ou pelo menos daquele que em grau superior a qualquer outro, que partilha da natureza divina, uma

inteligência e, por meio dela, a Deus (Plotino; Enéadas, 1996, III, 3, 4,10), e também uma parte discursiva livre das afecções do físico, ou seja, que se identificava mais com o pensamento do que com seu objeto; por isso, algumas vezes, Plotino chega a afirmar que a inteligência não está ou é parte da alma, mas do humano em contato direto com o divino. Por fim, a alma sensitiva-vegetativa estaria orientada mais para as coisas sensíveis, enquanto a discursiva estaria orientada ao Inteligível; o intelecto, por sua vez, participaria diretamente da inteligência divina. PLOTINO, V,3,25. PLOTINO. Enneadas. Testo greco a fronte. Edizione a cura de Giuseppe Faggin. Milano: Rusconi, 1996.

6 ARISTÓTELES, I, 8, 1256b, 11-12. Politica. Introducción, traducción y notas de Manuela García Valdés. Madrid: Gredos, 1988. 
vez que a cabeça que abriga o cérebro é a parte superior do ser humano que aponta para a parte superior do universo

À contribuição física ou precisamente antropológica de Aristóteles, haveríamos de esperar pelo desenvolvimento do platonismo tardo-antigo para que os animais fossem, a despeito das condições fisiológicas, compreendidos e aproximados do gênero humano desde uma perspectiva divina e transcendente, pela origem comum não só da alma, mas da capacidade intelectiva, própria desta.

\section{$O$ advento da metafisica platônica e uma nova perspectiva sobre a relação entre animais humanos e não humanos. A coalescência entre o fenomênico, a alma e o divino}

Os defensores do humano e de sua superioridade em detrimento dos demais animais, seriam ainda encontrados na época imperial e a partir de semelhantes argumentos, ou seja, que só os humanos poderiam participar do divino e pelas mesmas justificativas e características já apontada por Aristóteles. A novidade aqui é que haverá maiores vínculos com a metafisica, emergente nesse período em quase todos os âmbitos do pensamento e da sensibilidade humana. A posição ereta, a cabeça e os olhos voltados para o céu demostrariam que os homens se viam menos ocupados com o terreno do que com as estrelas, por meio das quais contemplavam o céu como lugar e morada dos deuses e/ou de Deus. Também aos humanos, a partir desse momento, foi atribuída a superioridade em relação aos demais animais por possuírem uma alma capaz de lhes dar a mais plena capacidade de uma razão transcendente ao divino. Portanto, mesmo aqui e sob essa nova perspectiva, defendeu-se aquele antropocentrismo pelo qual todos os viventes foram feitos para o homem e em virtude, inclusive, de uma razão causal divina. A capacidade cognitiva, enunciativa e sobretudo

7 ARISTÓTELES, II, 10, 656 a. Parte dos animais. Tradução: Maria de Fátima Sousa e Silva. Lisboa: Centro de Filosofia da Universidade de Lisboa; Imprensa Nacional - Casa da Moeda, 2010. 
intelectiva, deveria ser apanágio dos seres humanos e elemento definidor desta sua superioridade. Entretanto, como veremos, pensadores médios e neoplatônicos, haveriam de discutir tal posição demostrando que os animais não humanos possuiriam capacidades cognitivas tão profundas quanto aquelas encontradas nos seres humanos, embora as possuíssem e as exercitassem de acordo com sua situação cósmica e as condições ditadas pelo fenomênico.

Com o advento do pensamento platônico e a entrada em cena do Inteligível como realidade primeira, una e verdadeira, e, não obstante, causação e lugar das formas arquetípicas ou universais por meio das quais se originariam os modelos para a feitura do mundo dos fenômenos e do sensível consignado a multiplicidade e a individualidade, teríamos a afirmação de que todos os seres animados adviriam de uma só e mesma realidade original e inteligível; cabendo, ademais, à Alma abarcar e comunicar de modo coalescente, as esferas do aqui e do além, do sensível e do inteligível, na qual todos os seres animados, ou seja, providos de alma, participariam por meio dela da própria Inteligência divina. A partir desta perspectiva, nos parece bastante pertinente a consideração de Patrizia Pinotti ao afirmar que será com Platão que a diferença radical entre homens e animais parecerá não mais se sustentar, uma vez que "não de homens e animais se trata (...), mas de almas, de corpos, e dos destinos a todos reservados na escala dos seres no interior do ciclo da metensomatose"8. Portanto, "homens' e 'animais' não são outros que configurações somáticas, as quais vão assentar-se na alma"', isto é, uns e outros participam de uma mesma alma ou de uma mesma natureza essencial e causal, só residindo a diferença em função do estado corpóreo e de sua morfologia psíquica, ou seja, a partir de um estado que já não é mais o real e verdadeiro, que só poderia ser encontrado no Inteligível e, logo, na Alma, ou na sua parte a ele voltada. Corroborando com tal as-

\footnotetext{
8 PINOTTI, Patrizia, Gli animali in Platone: metafora e tassonomie. In: CASTGNONE, Silvana; LANATA, Giuliana. Filosofi e animali nel mondo antico. Genova: Edizioni ETS, 1994. p. 104.

9 Idem, p.104-105.
} 
serção haveremos de lembrar que o mesmo Platão afirmaria o fenômeno da transmigração das almas, ou seja, da metensomatose entre humanos e animais e em um ciclo que permitiria não só entender uma situação de queda (a qual Platão a vê inclusive na encarnação nos corpos femininos), - almas anteriormente humanas encarnando-se em condições corpórea, psíquica e somaticamente minoradas, como nos animais, mas igualmente de almas de animais encarnando-se em humanos -, portanto, deixando-se entrever que a alma, ela mesma, seria indistinta, una e perene em relação às vicissitudes do corpóreo e do físico, ficando, deste modo, a diferença tão só consignada a esta última natureza. A fenomenologia do vir ao mundo, do primeiro nascer, aos sucessivos renasceres a partir de então, estabeleceria, portanto, o modus operandi da alma, sua capacidade de potência, suas qualidades $\operatorname{cognitivas~}^{10} \mathrm{e}$ não a sua essência mesma. Por isso, nos dirá Platão que as almas que estão nos céus, desfrutando do descanso, ou de um estado de penitência, após seu último período de encarnação, deveriam

[...] escolher uma segunda existência, cuja escolha depende de cada uma delas. Desta maneira, uma alma pode entrar no corpo de uma besta, assim como uma alma bestial pode entrar no corpo humanal, desde que em outras de suas vidas anteriores tivesse sido a alma de um homem, pois as almas que nunca contemplam a verdade não podem assumir a forma humana".

Acrescenta Platão que só "a alma humana pode recordar-se das verdades eternas contempladas pela alma no momento em que se integrava no séquito de um deus"12, ou seja, o estado da alma modifica-se em função dos graus de suas capacidades, gravitando entre a intelecção mais pura e sua simples abstração das realidades sensíveis, e a partir delas. Assim, por sua condição fenomênica, o animal ver-se-ia menos

\footnotetext{
10 Idem, p. 110.

$"$ PLATONE, Fedro, 249 b. Tutte le Opere. Testo greco a fronte. Edizione a cura de Enrico V. Maltese e Francesco Adorno. Roma: Newton Compton Editori, 2009.

12 Idem, 249c.
} 
capaz que o humano de atingir a mais pura razão, ou ainda, aquela que se manifestava pelo atingimento e pela (re)união ao Inteligível divino em virtude da capacidade de reconhecê-la ao recordá-la. Isso, portanto, não significaria que os animais, providos eles também de alma, estariam de todo alijados daquele lugar divino, mas somente que eles teriam caído em um esquecimento absoluto sem possibilidade atual de rememoração. Daí conclui-se que, mesmos as almas que residiam nos indivíduos e em diferentes momentos, seriam sempre uma em si mesma, ou seja, em sua essência (divina) elas não se modificariam ou transformariam em função do gênero do ser fenomênico a qual viessem a residir ou encarnar-se por um tempo. A diferença estaria, portanto, na maior ou menor capacidade da alma encarnada de relembrar e, logo, de usufruir de sua natureza mais essencial e excelsa, de seu lugar original e congênito, o Inteligível.

Isso posto, cabe, também, ainda que muito pouco demoradamente, cuidar daquele aspecto da Alma em Platão afirmada como o elo de ligação e de participação entre o fenomênico e o âmbito das ideias; ou, se quisermos, ao estado e às condições da relação entre as almas individuais e a Alma cósmica. Seriam as primeiras, ou seja, as almas consignadas aos corpos, que permitiriam aos seres vivos tomados e em contato com o sensível, percebê-lo e experimentá-lo por meio da introspecção, geradora, por sua vez, da capacidade de percepção, sensação, prazer, vontade, etc., ${ }^{13}$ A alma deveria possuir várias partes ou faculdades ou, essencialmente, uma parte imortal - atributo, portanto, do divino no humano ${ }^{14}$ - que se manifestaria sobretudo pelo pensamento ou pela intelecção pura, e outra mortal, mais ligada às sensações do corpo ${ }^{15}$. Embora aqui nos refiramos às partes ou faculdades que compõem a alma humana, seria necessário, por aproximação, atribui-las à categoria mais ampla que envolve todo o

\footnotetext{
13 BRINKER, Wolfram, Alma (psychê). In: SCHÄFER, Chistian (org.). Léxico de Platão. São Paulo: Loyola, 2012. p. 36.

14 PLATONE, Timeu, god. Tutte le Opere. Testo greco a fronte. Edizione a cura de Enrico V. maltese e Francesco Adorno. Roma: Newton Compton Editori, 2009.

15 Idem, 69 c-d.
} 
ser animado, já que todas as almas individuais, que habitam animais ou humanos, ainda adviriam e participariam, mesmo que sob suas respectivas condições, a saber, da própria alma cósmica. A partir desta observação já seria possível entender que a residência fenomênica da alma no corpo, sob a perspectiva platônica, estabeleceria aí suas manifestações mais ou menos em consonância, ora com aquela parte mais elevada da alma que coalesce mesmo com o próprio divino, ora com sua parte mais baixa, ligada às percepções e sensações do sensível. Por isso, e a partir da aceitação da ideia da transmigração das almas, inclusive entre humanos e animais, se abrirá caminho para aquela cosmologia que fará desaparecer, no nível metafisico ao menos, a relação homem-animal pautada pela mais absoluta dualidade racional-irracional, sem qualquer possibilidade de conciliação, matização ou graduação com relação à categoria única do racional.

No entanto, será a partir dos médios e dos neoplatônicos, guardadas as especificidades de cada uma dessas escolas, que seria atribuída aos animais uma razão não totalmente distinta daquela dos homens e, por consequência, a eles seriam atribuídos consoantes valores e direitos morais, e ainda atitudes de respeito e benevolência. Na verdade, em âmbito neoplatônico, a justificação para uma maior dignidade aos animais viria exatamente desta sua atribuição de uma razão, cuja natureza seria consoante à própria razão humana, ficando a diferença, por sua vez, a cargo somente das nuances e matizes que a razão assistiria com relação a sua maior ou menor capacidade de abstração entre a experiência mais imediata do sensível e a abstração mais inteligível, chegando mesmo à esfera do divino. Será Plotino que justificará a unidade das almas por sua unidade no seio da Inteligência, uma vez que todos viriam e ainda participariam dessa mesma realidade causadora, e, por seu meio, do Uno.

Plotino, como é sabido, atribui a origem do ser e, logo, dos seres múltiplos deste, advindos de um único e mesmo princípio, o Uno, e, senão a ele mesmo, à Inteligência, sua segunda hipóstase que gera e contém em si toda a razão seminal de todo o vir a ser. Por sua vez, a Alma cósmica, terceira hipóstase, será aquela que levará à existência fenomênica as razões seminais contidas 
na Inteligência, gerando assim o múltiplo e os seres singulares. ${ }^{16}$ Também será ela que, em um sentido de ascensão ou regresso, levará os seres individuais e múltiplos à unidade e à perfeição do qual seriam congênitos. Tal modus cosmogônico nos informaria que, no presente cosmos sensível, não haveria disparidade ou pluralidade em relação à dignidade ou à essência dos seres senão na sua forma ôntica, ou seja, condicionada pelo estado fenomênico dos seres que, em si, os extrapolava por natureza e origem. Haverá de se lembrar que, para Plotino, os seres animados, providos de alma, não possuíam verdadeiramente uma alma particular ou totalmente individualizada de sua matriz cósmica, uma vez que, segundo ele, o corpo estava na alma e não a alma no corpo. ${ }^{17}$ Portanto, a natureza mais ou menos excelente dos seres quanto ao protagonismo da alma sobre o corpóreo e suas vicissitudes, ou, se quisermos, o uso mais ou menos pleno da razão inteligível sobre aquela tão só desperta pelo contato com o sensível, não poderia existir sem o concurso da alma voltada para a Inteligência que, pelos condicionamentos não estritos ao sensível, era apanágio da condição psíquico-fenomênica dos humanos. Contudo, a posse da Alma Universal e, por seu meio, a participação no próprio divino, era condição necessária de todo ser animado, fossem humanos ou não.

Porque se a Alma do universo se comunica com todos os animais particulares e cada alma particular é uma parte nesse sentido, então, se (a alma do universo) se dividisse não se comunicaria a cada um; mas se permanecesse a mesma, quer dizer que a alma total será onipresente por ser uma só, mesma e presente, por sua vez, em muitos ${ }^{18}$.

\footnotetext{
16 Plotino, Enéadas, 1996, IV, 8, 7, 5.

17 Plotino, Enéadas, 1996, I, 1, 8, 10 ss.

18 Plotino, Enéadas,1996, VI, 6, 3.
} 
Seguindo a Platão ${ }^{19}$, Plotino insiste que este Universo é, ele mesmo, um animal único que abarca dentro de si todos os animais ${ }^{20}$, e isso não em um sentido propriamente panteístico, mas panenteístico, ${ }^{21}$ pois o princípio divino antecede e não se imiscui com o sensível, embora este necessite estar contido naquele, sobretudo pela promoção da alma. Pois bem, a máxima plotiniana nos diz que todos os seres animados são providos de alma e, não obstante, suas próprias almas particulares estão infusas na mesma Alma cósmica ou divina, e, logo, não dela separadas ou expatriadas. Assim, todos os animais estariam investidos de razão, embora em graus diversos devido à multiplicidade das condições do fenomênico e das suas capacidades também múltiplas de se ligar ao divino e, portanto, de fazer o mais excelente uso da razão - daquela que chega ou mesmo participa do Inteligível, uma vez que, na verdade, nunca o tenha deixado, como já apontamos aqui sob os auspícios e as particularidades de Platão. Portanto, não deveríamos assistir aqui também a dicotômica relação seres racionais e seres irracionais, condicionando aos animais não humanos a irracionalidade, mas a verificação que estes, conformados por sua feição fenomênica, estariam menos facultados, ou ainda, dificultados de exprimir aquela mesma razão a todos os seres animados intrínseca. Em crítica aos estoicos - como o fará Porfírio - que acreditam que os animais possuíam uma alma tão só ligada aos sentidos, se expressa Plotino:

E que não venham dizendo que os animais morrem pela retirada do hálito ou do sangue. Porque é verdade que sem eles não podem existir, como tampouco sem outras muitas coisas as quais não se pode identificar com a alma, e, contudo, não é o hálito nem o sangue o que permeia todas as coisas, senão a alma²2.

\footnotetext{
19 Platão, Timeu, 3od 3-31.

20 Plotino, Enéadas, 1996, IV, 4, 4.

${ }^{21}$ GEISLER, Norman, Enciclopédia de apologética. São Paulo: Editora Vida, 1999. p. 331.

22 Plotino, Enéadas, 1996, IV, 4, 7.
} 
A Alma permeia todas as coisas, anima e dignifica todos os seres os quais necessariamente a contém. Vivifica a vida animal, lhe dá inteligência e capacidade racional, ou, ao menos, o quanto a sua condição sensível o permita. Portanto, a capacidade racional dos animais não humanos, não estaria consignada às categorias absolutas como presença/ausência, totalidade/nulidade, existência/não existência, mas a nuances ou potencialidades mais ou menos exprimíveis de acordo com a condição fenomênica animal, insistamos. Seria a condição sensível com suas restrições próprias de sua natureza física ou mesmo psicofísica que permitiria, em maior ou menor grau, o uso da razão o mais plenamente possível a todos os seres animados a ela facultados. Por sua vez, dificilmente se negaria o uso de alguma forma da razão aos animais, pois, pelo instinto, era patente neles a percepção e a intuição que, ineludivelmente, recobrariam e afirmariam algum grau de abstração ou raciocínio. Este seria um dos principais argumentos de Porfírio, como veremos aqui e a seu tempo.

Por fim, o discurso sobre a ausência de razão nos animais, que muitas escolas filosóficas antigas como a estoica e a peripatética promoviam, estaria em incongruência também com a tese neoplatônica, que afirmava a participação de todos os seres animados na alma divina, da qual, aliás, todos teriam se originado e seriam conaturais. Assim, para Plotino, se há uma só Alma que a todos originou e, mesmo no estado presente, a todos envolve e vivifica, não poderiam haver categorias absolutamente discordantes de seres como aquelas do racional e do irracional.

Ademais, se não há mais que uma só alma, como ocorre de uma ser racional e outra irracional e que uma é a que há nos animais e outra distinta que existe nas plantas? [...] mas, se, pelo contrário, aceitamos essa tese, então nem o universo será uno nem se achará um único princípio para as almas ${ }^{23}$.

23 Plotino, Enéadas, 1996, IV, 4, 9. 
Contudo é necessário reiterar que mesmo as almas particulares dos seres animados participassem da própria Alma universal, as vicissitudes próprias do fenomênico haveriam de mitigar suas manifestações mais excelentes. Referindo-se à Alma que realizou o sensível e o próprio mundo animal de acordo com uma ordem na qual se inscreveriam entes mais ou menos capazes de fazer um uso parcialmente pleno da sua parte divina (ou seja, aquela parte da alma voltada à Inteligência e ao Uno), Plotino seguirá de perto Platão, que já havia considerado tal disparidade quanto ao uso da razão pelos animais como consequência de uma vida anterior mais ou menos virtuosa, mais ou menos dedicada ao uso da razão plena ou inteligível. Dito de outro modo, a condição animal tal como se originou - homens, aves, animais terrestres, peixes e demais seres aquáticos, como lemos no Timeu -, seriam condições fenomênicas, cujas almas foram a elas designadas ou os seres as escolheram, em função de uma queda devida por uma existência anterior marcada pela ignorância, pelo afastamento da razão intelectiva ou pelo seu mau uso. "É de acordo com todos esses pressupostos que outrora e agora os seres-vivos se transformam uns nos outros, de acordo com o fato de perderem ou ganharem em intelecto ou em demência"24. Já em Plotino é a razão divina que em uma ordem decrescente estabeleceu primeiro os deuses, e abaixo deles os daemones e, em uma outra e mesma escala, os homens e os animais, condicionando, portanto, a diferença entre eles à situação fenomênica, uma vez que tal diferença se daria "não da inveja, senão da Razão que contém uma policromia de idealizações" ${ }^{\prime 25}$. Segundo o filósofo neoplatônico, a diversidade seria desejável, uma vez que propiciaria a beleza própria a essa realidade, como a diversidade de cores a uma pintura.

No entanto, Plotino também admite que a qualidade ou a potencialidade da razão que condiciona e se vê condicionada pela fenomenologia dos seres animais, humanos e não humanos, já tenham suas diferenças

\footnotetext{
24 Platão, Timeu, 92c.

25 Plotino, Enéadas, III, 3, 2.
} 
estabelecidas ainda no Inteligível, pois uns e outros já possuiriam suas versões arquetípicas ou seminais muito próximas a seu estabelecimento no múltiplo e no individual a partir do sensível. Assim como haveria um homem arquétipo, puramente espiritual e universal, também o haveria para cada um dos seres animais.

[...] o cavalo não originado tinha que existir antes daquele que havia de existir posteriormente. Se, pois, existia antes da geração do cavalo, e não foi idealizado para que se originasse, segue-se que quem tinha o cavalo do além o tinha consigo sem olhar as coisas do aqui, e que nem ao cavalo nem aos demais animais do além se teria para produzir os daqui, senão que os do além existiam, enquanto que os de aqui surgiram como consequência necessária daqueles do além. Não era possível, efetivamente, deter-se nos do além. Porque quem poderia deter uma potência tão capaz de permanecer como de seguir adiante? ${ }^{26}$

Tomando como exemplo o cavalo, Plotino demonstra que a existência dos animais e, portanto, não só dos seres humanos, como quisera mais tarde a tradição platônica cristã, seria também essencialmente espiritual. O cavalo arquetípico existe independentemente dos cavalos sensíveis, pela potência da alma criadora esses seriam gerados por uma necessidade desta potência, assim como um artesão que por sua imperativa energia criativa modelaria e criaria tantas cópias quanto fosse possível a partir de um modelo preexistente. Plotino, ademais, se impõe a responder uma questão cadente também aqui para nós: Porque estaria também em Deus uma multidão de arquetípicos de animais irracionais e não só o arquétipo do humano que é racional? Responde então que não podem ser de todo irracionais aqueles que se originaram e habitam por essência no Inteligível, como alguns acreditariam:

${ }^{26}$ Plotino, Enéadas, VI, 7, 8, 5. 
Contudo, como pode haver ininteligência ou irracionalidade naquele em que estão ou de onde procedem todas e cada uma das coisas? Antes de discutir e afrontar esta dificuldade, atentemo-nos de que o homem daqui não é da mesma qualidade que o do além, de maneira que tampouco os demais animais são além da mesma índole que os daqui, senão que os do além há que tê-los em maior estima que os daqui. Ademais, tampouco o racional existe além; aqui será talvez racional, mas além existe o suprarracional ${ }^{27}$.

Plotino parece defender aqui a ideia de que se deve atribuir aos animais uma razão apropriada a sua condição designada pela natureza em lugar de uma não razão. "Pois, porque no além o modo de inteligência do homem é distinto no homem assim como é nos demais animais; assim também é distinto o modo de raciocinar. E é que, de certo modo, ainda nos demais animais há muitas operações que são obra da razão". ${ }^{28}$ Reitera, assim, aquele argumento que insistiria acerca da unidade dos seres pela unidade no Espírito, ou seja, tanto aquela unidade que remete à Inteligência quanto à Alma divina. Portanto, e a despeito das limitações e dos limites do corpóreo, aos animais se deveria atribuir uma razão não de todo distinta dos homens, assim como do divino que a todos envolvia

Há que ter em conta que as numerosas vidas, que são como movimentos, e as numerosas intelecções, não podiam ser todas iguais (...). E por isso, entre as intelecções, umas são deuses outras formam uma espécie segunda, conhecida aqui pelo nome "racional", e a uma terceira chamada "irracional". Mas além, ainda o que chamamos "irracional" é razão e ainda o que chamamos "ininteligência" é inteligência. Porque quem pensa "cavalo" é a inteligência, e o pensamento de "cavalo" é inteligência 29.

\footnotetext{
27 Plotino, Enéadas, VI, 7, 9, 5.

28 Plotino, Enéadas, VI, 7, 9, 10.

29 Plotino, Enéadas, 1996, VI, 7,9,15.
} 
Plotino conclui que no Inteligível não há nada que não seja inteligência. E se lá reside o protótipo de todos os animais, inclusive na sua perfeição e unidade, todo e qualquer animal se constitui, em si, inteligência, e naturalmente a realizaria em alguma medida estando no mundo. A cosmologia plotiniana, deste modo, atenuaria o dualismo platônico entre o sensível e o inteligível, a ponto de negar a própria existência efetiva do primeiro, alçando toda criatura viva à dignidade e à qualidade do ser pela alma. A condição fenomênica dos animais não humanos estava assim também salvaguardada a partir de então, como demostrarão os discípulos e seguidores de Plotino e sua tradição.

\section{Os animais e o seu pleno direito à razão. $O$ neoplatonismo de Porfírio, Orígenes e Celso}

Porfírio de Tiro, discípulo e "biógrafo" de Plotino, ordenador de suas Enéadas, autor de inúmeras e importantes obras sobre o neoplatonismo e sobre sua defesa diante do cristianismo emergente, uma vez que um e outro se debatiam por questões suscitadas por problemas essencialmente metafísicos, ainda que cada qual a sua maneira, também escreveu um importante tratado sobre os animais, Sobre a abstinência dos animais, cujos problemas e abordagens serão bastante correlatos àqueles escritos pelo medioplatônico Plutarco ${ }^{30}$, a quem, aliás, ele retoma com frequência e muitas vezes ad litteram. Constituído de quatro livros, o tratado Sobre a abstinência dos animais tem no terceiro livro as questões mais pujantes a nossa causa, a saber, sobre a natureza própria da razão dos animais, que a aproxima mais do que a distingue daquela encontrada nos seres humanos.

\footnotetext{
30 Plutarco dedicou ao menos três obras a respeito dos animais: Sobre a inteligência dos animais, Os animais são racionais ou o Grillo e Sobre comer carne. Certamente Plutarco, por meio destes três tratados foi o autor mais utilizado no período e mesmo posteriormente para se tratar da questão animal e na defesa de sua dignidade e justiça perante os homens, e isso devido sobretudo a este autor também reenvidar a eles o uso da razão, que deixava entrever o uso da inteligência, da linguagem, da comunicação com os deuses, etc. BACARLETT PÉREZ, María Luisa. Plutarco y los animales. La Colmena. Revista de la Universidad autônoma del Estado de México n. 65/66. jan.-jun. 2010, p. 27.
} 
Portanto, uma outra razão, mas ainda uma razão inteligente, embora manifesta por meio de um modus operandi próprio e em consonância a sua condição sensível, tal como já havia demonstrado Plutarco ${ }^{31}$.

Criticando os estoicos e o seu antropocentrismo que relegava os animais a uma não razão, portanto, entre outros juízos, justificando sua plena submissão à vontade e servidão humana, Porfírio começa por dizer que tal argumento, a saber, a afirmação de sua irracionalidade, teria um duplo aspecto, e que certamente para ele não se sustentaria: 1) a incapacidade dos animais para a pronúncia ou a comunicação verbal; 2) as características próprias da disposição interna do ânimo..$^{32}$ Quanto ao primeiro aspecto, a incapacidade dos animais de verbalizar e, portanto, de comunicar "um som que, por meio da língua, manifesta as paixões internas da alma"33, tal consideração seria uma ignomínia, pois, segundo Porfírio, os animais emitem sons que, ainda que inteligíveis aos ouvidos humanos, não seriam por isso faltosos do poder de comunicar e externar inclusive exercícios mentais complexos, como os pensamentos, ou como deseja se expressar: "o som que se emite em silêncio no interior da alma". Logo, a não compreensão humana da fala animal não poderia por isso eximi-la do próprio poder de comunicar, e comunicar de forma efetiva e compreensivamente. Para dar maior envergadura a esta sua tese, passará Porfírio a realizar um exercício etnológico-linguístico, ou seja, a partir de exemplos da própria pluralidade e especificidades das línguas humanas, também elas marcadas, muitas vezes, pela incompreensão entre si: afirma que não é pelo fato de que os gregos não compreenderem a língua dos bárbaros (ou seja, das gens não gregas) que eles não possuíam uma língua inteligível e comunicante. E tão logo, amparado por essa verificação anterior, conclui a favor da capacidade em si comunicante dos sons

31 Plutarco, III, 960B. Sobre la inteligencia de los animales. Obras Morales y de costumbres. Madrid: Gredos, 2002.

32 Porfirio, III, 3, 3. Sobre la Abstinencia. Traducción, introducción y notas de Miguel Periago Lorente. Madrid: Gredos, 1984.

33 Porfírio, Sobre a abstinência, III, 3, 3 . 
emitidos pelos animais, estabelecendo-se a incompreensão, portanto, como um produto de quem ouve.

Porque quais razões ficam excluídos dela ${ }^{34}$ os animais que emitem sons? E porque não pensam suas experiências antes inclusive de dizer o que desejam dizer? Chamo pensamento ao som que se emite em silêncio no interior da alma. Por conseguinte, se se emite um som pela língua, como quer que soe, já seja bárbaro, grego, de cachorro ou de boi, os seres vivos que os produzem estão dotados sem dúvida de uma capacidade de raciocínio; os homens falam, por sua parte, de acordo com as leis humanas, e os animais a teor das leis dos deuses e da natureza que a cada um lhes tocou a sorte" 35 .

E continua para arrematar sua argumentação ainda sob o aspecto da linguagem:

Mas se não o compreendemos, que importa isso? Porque tampouco os gregos compreendem a língua dos estrangeiros, dos que se criaram na Ática ou a dos escitas, trácios ou sírios; senão que os sons de uns lhes resulta aos outros como grunhidos de pássaros ${ }^{36}$.

Porfírio então argumenta que a não compreensão da língua do outro não significaria que ela estivesse, em si e por si mesma, desprovida de toda capacidade de significação e compreensibilidade. Tais qualidades ou sua falta seriam resultado da inadequação receptiva do ouvido do receptor, ou sua incapacidade para compreender, e não do falante e de sua aptidão cognitiva pela qual, não obstante, todo som por ele emitido poderia ser a reverberação de uma ideia ou de uma experiência raciocinada e eficaz. A novidade é que Porfírio estende esta argumentação para a comunidade animal não humana ao atribuir-Ihes igualmente uma linguagem que a gens

\footnotetext{
34 Isto é, a capacidade enunciativa que se manifesta pela voz.

35 Porfírio, Sobre a abstinência, III, 3, 3.

${ }^{36}$ Idem.
} 
humana não teria a capacidade de compreensão, o que em nada invalidaria sua potencial capacidade de poder se comunicar e a partir mesmo de um raciocínio lógico. A favor desta sua posição, argumenta Porfírio que haveriam pessoas que inclusive conseguiriam entender as mensagens da comunicação animal, quando eles prenunciavam acerca de vaticínios ou acontecimentos futuros dos mais diversos, assim como quando transmitiam as mensagens dos deuses. Também pedia que se levasse em consideração, que os sons emitidos pelos animais estavam marcados por variações de gravidade, cadência, intensidade, demostrando, portanto, que de acordo com as situações que se encontravam ou se viam submetidos, como a dor, ao chamamento, a fome, etc. ${ }^{37}$, eles respondiam de forma consoante a cada uma dessas situações, condições ou sentimentos. Por fim, a não compreensão dos sons animais e das formas de sua dicção, não significava ininteligibilidade em si mesmos, mas o fruto de uma razão específica que seria por esses sons formulado e externado.

O segundo gênero de argumentação de Porfirio a respeito da sua defesa da razão presente nos animais é com relação a sua disposição interior. A favor dessa argumentação, o autor compara as disposições do humor humano a dos animais; como nós, tomam atitudes que ele chama de antinaturais, assim como outras movidas pelas paixões naturais. Possuem memória "que resulta ser precisamente de capital importância para a aquisição da razão e inteligência", demostram maldade e inveja "ainda que não manifestem com tanta profusão como os humanos" ${ }^{38}$; demostram amizade e desconfiança; conseguem perceber as diferenças existentes entre os signos que constituem nossa língua e, logo, fazem uso da razão. Nota que os animais possuem um senso de justiça como observa nas formigas e nas abelhas que reconhecem seus membros e os respeitam; cita uma espécie de pombo que reconhece o sentido de fidelidade afetiva,

\footnotetext{
37 Porfírio, Sobre a abstinência, III, 4, 2.

38 Porfírio, Sobre a abstinência, III, 10, 4.
} 
pois matam seu par se o surpreendem no ato do adultério ${ }^{39}$; cita ainda aves que conseguem perceber e antever a mudança no clima. Por fim, e de acordo com a concepção de que as afecções do sensível sequer poderiam ser percebidas e acolhidas pelos sentidos nos seres vivos sem o concurso da alma que recebe e interioriza as impressões de fora, tornando-as efetivamente do sujeito e para ele, da mesma forma os animais, também eles seres sencientes, teriam alma e por ela a capacidade de abstração e de raciocínio a partir desta sua mesma capacidade de recepção interior.

Pode-se admitir que a alma se visse afetada em coincidência com o corpo, e que sua afecção se deva a uma boa ou má disposição dele, mas de nenhum modo se mude sua própria natureza. Mas se a alma tão somente experimenta afecções conjuntas com o corpo, e o utiliza como um instrumento, pode ganhar muitas realizações, valendo-se de um corpo constituído de diferente maneira ao nosso ${ }^{40}$.

Então, o corpo está para a alma e não alma para o corpo. Humanos e animais difeririam, portanto, pelos graus e pelas nuances do uso razão, e não por sua inexistência, já que a razão é dada em possibilidade a todo aquele que participa da alma e da alma divina, como acreditavam os neoplatônicos. Ademais, possuir um corpo animado que interage com o meio natural, também ele animado, já seria prova que se possuía uma alma. $\mathrm{E}$ mais, a disposição da alma, da sua potencialidade (da qual o uso mais ou menos plano da razão) estaria condicionada pelo estado corpóreo, mas nunca por ele engendrado, dado ou tirado em absoluto.

Para concluir, citemos outro neoplatônico, Orígenes de Alexandria, que, embora cristão, foi um dos maiores expoentes do neoplatonismo para seu meio e credo, haja vista que fundou uma exegese profundamente devedora das ideias e especulações neoplatônicas para se ler e compre-

39 Porfírio, Sobre a abstinência, III, 11, 2.

40 Porfírio, Sobre a abstinência, III, 3, 8. 
ender as Sagradas Escrituras. Acredita-se, ademais, que foi condiscípulo do próprio Plotino na escola neoplatônica de Amônio Sacas, embora não no mesmo estrito período.

Da sua parte, mais do que consignar os animais a um lugar e a um estado de inferioridade e submissão ao homem, como fariam os filósofos-teólogos cristãos a partir da cosmogonia do Gênesis ${ }^{41}$, Orígenes os encontra e os dá a conhecer também entre os inteligíveis e, logo, fundados por esta mesma dignidade. O Comentário ao Cantar dos Cantares de Orígenes, para além de sua beleza e modus hermenêutico especular da cosmovisão cristã em relação à essência dos seres e da sua personificação no sensível, também dar-nos-ia a saber que Orígenes comungava da ideia de que a atual realidade seria na verdade uma imagem mitigada e distorcida do mundo inteligível, e que, a partir do cristianismo, passará a residir na mente de Deus. Portanto, o mundo dos fenômenos, estaria constituído por signos, cuja essência e significado verdadeiro residiria nos seus arquétipos divinos ou nas razões seminais existentes na mente do criador. É no bojo desta concepção cosmogônica/cosmológica pela qual todo o existente, todos os seres criados, deveriam encontrar sua origem e justificação no inteligível divino que Orígenes, em estreita comunhão com Plotino, nos informaria que mesmo os animais não humanos teriam igualmente uma origem divina e, não obstante, seu arquétipo no suprassensível, o que nos parece estar em claro contrassenso a ideia cristã acerca da própria ontologia animal apregoada pelo livro do Gênesis e adotada pelo cristianismo, inclusive por Orígenes em outros escritos seus.

A diferença em relação a Plotino, para o qual, os arquétipos dos seres nasceram da Inteligência divina, a segunda hipóstase do Uno que em si nada pensa e nada cria, e nela eternamente residem enquanto arquétipos universais (embora já tendendo ao múltiplo), só cabendo à Alma torná-los efetivamente múltiplos e individuais, a versão cristã aqui representada por

${ }^{41}$ Gn 1, 26-28. 
Orígenes, afirmaria que os seres arquétipos constituiriam, na verdade, as razões seminais pensadas por Deus, e mesmo já no princípio existentes segundo certo grau de diferenciação e de uma corporeidade ainda que etérea. Ao atribuir um valor simbólico ao cervo e à gazela referenciados pelo Cantar dos Cantares, Orígenes de Alexandria, também encontrará ocasião aí de refletir sobre a origem desses seres animais

Por conseguinte, se, segundo o que temos comprovado anteriormente, todas as coisas que estão manifestas têm relação com as coisas que estão ocultas, não cabe a menor dúvida de que este cervo visível e a gazela, que no Cantar são descritos segundo as características da natureza corporal, também podem ser referidos segundo algumas causas de coisas incorpóreas (...) Se, diferentemente, buscamos os cervos invisíveis, cuja imagem e forma leva esse animal corpóreo, acharás que pela voz do Senhor podem ser conduzidos até a suma perfeição ${ }^{42}$.

Orígenes, portanto, aceita a ideia acerca da existência de arquetípicos divinos como origem e justificação para cada uma das criaturas sensíveis, encontradas em sua perfeição e unidade na Inteligência divina, e isso mesmo em relação aos animais não humanos, como já afirmara, sob sua perspectiva, Plotino. Por sua vez, Celso, filósofo também neoplatônico, o qual Orígenes entra em contenda e escreve o seu Contra Celso para rebater a sua crítica ao cristianismo, defenderia igualmente os animais, afirmando possuírem razão. Chegaria mesmo a afirmar que os animais possuíam certa ciência; conseguiam discernir, em seus graus e eficiências, as benesses dadas pela natureza. Assim, saberiam, por exemplo, quais plantas e minerais que thes serviriam para a cura, inclusive de modo a aplicá-los para o benefício de suas crias. E, quanto Orígenes, rebatendo a Celso, atribuiria esta capacidade tão só ao instinto e não a um discernimento que exigiria o uso da própria razão, o filósofo "pagão" afirmaria,

42 Orígenes de Alexandria, III, 2,9, 30. Comentário al Cantar de los Cantares. Madrid: Ciudad Nueva, 2007. 
uma vez mais, que os animais raciocinam assim como os humanos ${ }^{43}$. Celso admite que os animais possuíam um conhecimento do divino tal como os humanos afirmavam possuir; para tanto, afirma pela boca de Orígenes:

\begin{abstract}
Mas se porque os homens têm ideias divinas se creem superiores aos restantes animais, saibam os que isso afirmam que os mesmos pretenderão muitos dos outros animais. E com muita razão. O que se pode, com efeito, acreditar como mais divino que prever e predizer o que está por vir? Agora bem, isto aprendem os homens dos animais. (...) Pois bem, as aves e demais animais que possuem da parte de Deus qualidades proféticas, nos avisam por meio de signos, de modo que estejam naturalmente mais próximos do trato com Deus e sejam mais sábios e mais queridos de Deus. E se homens sinceros dizem que os animais conversam conversas mais sagradas que a nossa, claro está que eles conhecem o que dizem (... $)^{44}$.
\end{abstract}

Orígenes, como cristão, rebate a Celso quanto à capacidade dos animais de estar em contato direto com o divino e constituir-se em seu porta-voz, dado que a própria profecia ou demais augúrios seriam considerados comumente obra dos demônios pelos cristãos; assim como se oporá à afirmação do filósofo que os animais gozariam não só de uma razão intelectiva, mas inclusive daquela advinda de uma estreita conexão com a própria razão divina: "e quem não se horrorizaria de um homem que afirma serem mais caros a Deus uma raposa ou um lobo, uma águia e um gavião, que a própria natureza humana?45 Orígenes, como cristão que é, já deverá seguir os cânones do Gênesis bíblico, segundo o qual Deus criou os homens e os restantes animais em um grau distinto não só de dignidade, mas inclusive de natureza ontológica, pois só ao primeiro fez-se tão espiritual a ponto de assemelhar à semelhança de Deus ${ }^{46} \mathrm{e}$, logo, nem mesmo o homem par-

\footnotetext{
43 Orígenes de Alexandria, IV, 86. Contra Celso. Madrid: BAC, 2002.

44 Orígenes de Alexandria, Contra Celso, IV, 88.

45 Orígenes de Alexandria, Contra Celso, IV, 97.

46 GILSON, Étienne. Introdução a Santo Agostinho. São Paulo: Paulus, 2011. p. 398.
} 
ticiparia da essência do próprio criador, excluindo, assim, absolutamente qualquer dignidade divina a outras criaturas não humanas.

A título de breve conclusão, poderíamos dizer que a filosofia antiga, mesmo aquela mais apegada às circunstâncias do suprassensível, nunca se alijou, como nós o fizemos modernamente, da natureza como objeto seu e em sua multividente dimensão. $O$ antropocentrismo cristão e aquele revigorado pelo iluminismo foi, neste sentido, muito mais severo do que o arrazoado pelos antigos. Vale dizer que causou uma tão grande fissura entre o mundo humano e o mundo da natureza que colaborou para o agravamento da compreensão sobre nós mesmos.

\section{Referências}

ARISTÓTELES. Politica. Introducción, traducción y notas de Manuela García Valdés. Madrid: Gredos, 1988.

ARISTÓTELES. Parte dos Animais. Tradução: Maria de Fátima Sousa e Silva. Lisboa: Centro de Filosofia da Universidade de Lisboa: Imprensa Nacional Casa da Moeda, 2010.

ORÍGENES DE ALEXANDRIA. Comentario al Cantar de los Cantares. Madrid: Ciudad Nueva, 2007.

ORÍGENES DE ALEXANDRIA. Contra Celso. Madrid: BAC, 2002.

PLATONE. Fedro. Tutte le Opere. Testo greco a fronte. Edizione a cura de Enrico V. maltese e Francesco Adorno. Roma: Newton Compton Editori, 2009. PLATONE. Timeo. Tutte le Opere. Testo greco a fronte. Edizione a cura de Enrico V. maltese e Francesco Adorno. Roma: Newton Compton Editori, 2009. PLATONE. Fedone. Tutte le Opere. Testo greco a fronte. Edizione a cura de Enrico V. maltese e Francesco Adorno. Roma: Newton Compton Editori, 2009. PLOTINO. Enneadas. Testo greco a fronte. Edizione a cura de Giuseppe Faggin. Milano: Rusconi, 1996.

PLUTARCO. Sobre la inteligencia de los animales. Obras Morales y de costumbres. Madrid: Gredos, 2002.

PORFIRIO. Sobre la Abstinencia. Traducción, introducción y notas: Miguel Periago Lorente. Madrid: Gredos, 1984. 
BACARLETT PÉREZ, María Luisa. Plutarco y los animales. La Colmena, Ciudad del Mexico, n. 65/66, p. 23-30, jan./jun. 2010.

BRINKER, Wolfram. Alma (psychê). In: SCHÄFER, Chistian (org.). Léxico de Platão. São Paulo: Loyola, 2012. p. 35-39.

CASTGNONE, Silvana; LANATA, Giuliana. Filosofi e animali nel mondo antico. Genova: Edizioni ETS, 1994.

GEISLER, Norman. Enciclopédia de apologética. São Paulo: Editora Vida, 1999.

GILSON, Étienne. Introdução a Santo Agostinho. São Paulo: Paulus, 2011.

MARINI, Sergio. Filosofi, animali, questioni animale. Milano: Educatt, 2012.

LANATA, Giuliana. Antropocentrismo e cosmocentrismo nel pensiero antico. In: CASTGNONE, Silvana; LANATA, Giuliana (org.). Filosofi e animali nel mondo antico. Genova: Edizioni ETS, 1994.

PINOTTI, Patrizia, Gli animali in Platone: metafora e tassonomie. In: CASTGNONE, Silvana; LANATA, Giuliana (org.). Filosofi e animali nel mondo antico. Genova: Edizioni ETS, 1994. 